\title{
DETERMINAN PEMBIAYAAN BERMASALAH \\ PADA BANK SYARIAH DI INDONESIA
}

\author{
Rina Destiana \\ Universitas Swadaya Gunung Jati \\ rinadestiana@unswagati.ac.id
}

\begin{abstract}
This study aimed to examine and analyze the influence of liquidity, efficiency, capital and inflation on non-performing financing at sharia banks in Indonesia. The research data is secondary data obtained from the Financial Services Authority and Bank Indonesia. The data were analyzed using multiple linear regression analysis. Before the data is analyzed further, classical assumption test is done which include normality test, multicolinearity test, heteroscedasticity test and autocorrelation test.

Based on the hypothesis test using $t$ test, it is concluded that only the capital has an effect on the problem financing, while the liquidity, efficiency and inflation do not affect the problematic financing of syariah bank in Indonesia.
\end{abstract}

Keywords: efficiency, inflation, liquidity, capital, problem financing 


\section{PENDAHULUAN}

Hadirnya bank syariah semenjak tahun 1992 ternyata memberikan nuansa dan warna bagi industri perbankan di Indonesia. Kehadiran bank syariah di Indonesia bukan hanya untuk mengakomodasi kepentingan masyarakat Indonesia yang mayoritas beragama islam, akan tetapi lebih kepada adanya faktor manfaat dari bank syariah dalam memfasilitasi kegiatan ekonomi dan lebih umum kepada krisis (Supriyatni dan Sandra, 2008). Sebagaimana bank konvensional, bank syariah menjalankan perannya sebagai mediasi keuangan (financial intermediary) yaitu menjembatani pihak-pihak yang memiliki kelebihan dana dengan pihak-pihak yang membutuhkan dana. Bank mengumpulkan dana dari masyarakat kemudian menyalurkan kembali dana tersebut dalam bentuk pembiayaan.

Bank syariah di Indonesia ternyata tumbuh dan berkembang luar biasa pesat. Menurut data OJK, berdasarkan statistik perbankan syariah, hingga akhir tahun 2016, jumlah jaringan kantor bank syariah sebanyak 473 kantor cabang bank umum syariah (BUS), 1.207 kantor cabang pembantu BUS, 189 kantor kas BUS, 149 kantor cabang Unit Usaha Syariah (UUS), 135 kantor cabang pembantu UUS, 48 kantor kas UUS, 95 kantor cabang Bank Pembiayaan Rakyat Syariah (BPRS) dan 192 kantor kas BPRS, dengan total jaringan kantor sebanyak 2.488 kantor di seluruh Indonesia. Pesatnya pekembangan bank syariah di Indonesia, ternyata tidak menjadikan bank syariah terbebas dari masalah. Beberapa kendala yang dihadapi oleh bank syariah hingga saat ini, diantaranya masalah permodalan, efisiensi, sumber daya manusia, teknologi, inovasi produk, kualitas aset dan lain sebagainya.

Dari sekian banyak kendala yang dihadapi bank syariah, satu permasalahan penting yang dihadapi oleh industri perbankan syariah adalah mengenai pembiayaan bermasalah. Pembiayaan bermasalah atau Non Performing Financing (NPF) merupakan fenomena yang terjadi dalam industri perbankan syariah karena salah satu aktivitas utama bank syariah adalah penyaluran pembiayaan. Dalam perkembangan terakhir, pembiayaan bermasalah atau NPF bank syariah ternyata relatif tinggi. Bahkan menurut data tahun 2015, pembiayaan bermasalah bank syariah lebih tinggi dibandingkan bank konvensional (www.republika.co.id, 2016). Otoritas Jasa Keuangan juga mencatat rasio pembiayaan bermasalah bank syariah pada kuartal I 2017 masih cukup tinggi. Berdasarkan data OJK, per Februari 2017, NPF pada sektor perdagangan besar dan industri pengolahan mengalami peningkatan masing-masing menjadi 9,63 persen dan 5,54 persen dari tahun sebelumnya yaitu 7,46 persen dan 4,88 persen (www.republika.co.id, 2017).

Pembiayaan bermasalah

(Non

Performing Financing) menunjukkan besarnya risiko pembiayaan yang dihadapi oleh bank syariah. Berdasarkan ketentuan Bank Indonesia, pembiayaan bermasalah (Non Performing Financing) adalah pembiayaan dengan kualitas kurang lancar, diragukan dan macet (Peraturan BI No. 6/9/PBI/2004). Pembiayaan bermasalah (NPF) adalah pembiayaan yang mengalami kesulitan dalam hal pelunasannya dikarenakan faktor-faktor atau ada unsur kesengajaan atau karena kondisi di luar kesanggupan peminjam. NPF adalah rasio yang menunjukkan perbandingan antara jumlah pembiayaan bermasalah dengan jumlah pembiayaan yang dikucurkan oleh bank syariah.

Non Performing Financing (NPF) merupakan rasio pembiayaan bermasalah di bank syariah. Apabila pembiayaan bermasalah meningkat maka risiko terjadinya penurunan profitabilitas semakin besar. Apabila profitabilitas menurun, maka kemampuan bank dalam melakukan ekspansi pembiayaan berkurang dan laju pembiayaan menjadi turun. Risiko pembiayaan yang 
diterima bank merupakan salah satu risiko usaha bank, yang diakibatkan dari tidak dilunasinya kembali pinjaman yang diberikan atau investasi yang sedang dilakukan oleh pihak bank (Muhammad, 2005).

Indikasi pembiayaan bermasalah dapat dilihat dari perilaku rekening, perilaku kegiatan bisnis, perilaku nasabah dan perilaku makroekonomi (Rahmawulan, 2008 dalam Firdaus, 2015). Tingginya pembiayaan bermasalah bank syariah bisa disebabkan berbagai faktor. Faktor-faktor tersebut bisa disebabkan dari pihak bank (kreditur), dari pihak peminjam atau debitur serta disebabkan dari faktor luar selain kedua faktor tadi. Menurut Siamat (2005), faktorfaktor yang menyebabkan kredit bermasalah dari perspektif bank dapat disebabkan dari faktor internal, faktor eksternal dan loan review. Faktor internal ini berkaitan dengan kebijakan maupun strategi yang dijalankan oleh bank tersebut seperti kebijakan perkreditan yang ekspansif, pelanggaran dalam pelaksanaan prosedur perkreditan, tata kelola administrasi dan pengawasan kredit yang lemah, lemahnya informasi kredit, maupun niat kurang baik dari pihak bank. Sedangkan faktor eksternal yang menyebabkan timbulnya kredit atau pembiayaan bermasalah berkaitan dengan kegiatan usaha debitur misalnya kegiatan ekonomi menurun dan tingginya suku bunga kredit, pemanfaatan kondisi persaingan bank yang tidak sehat oleh debitur, kegagalan usaha debitur, maupun musibah yang dialami oleh debitur. Untuk faktor dari loan review adalah gagalnya penilaian kredit oleh pejabat kredit. Faktor-faktor yang mendorong terjadinya kredit atau pembiayaan bermasalah dapat disebabkan oleh tiga hal, yaitu dari pihak bank itu sendiri atau kreditur, dari pihak peminjam atau debitur, serta di luar kedua pihak tersebut. Beberapa hasil penelitian menemukan bahwa faktorfaktor yang menjadi penyebab pembiayaan bermasalah pada bank syariah diantaranya likuiditas, efisiensi, permodalan dan inflasi.
Tingkat likuiditas bank syariah diprediksi menjadi salah satu faktor penyebab pembiayaan bermasalah. Jika kondisi bank syariah lebih likuid maka bank syariah jadi lebih fleksibel dalam mengucurkan pembiayaan walaupun tingkat kemacetan sedang naik. Biasanya bank syariah lebih antusias untuk mengatasi pembiayaan bermasalah jika kondisi likuiditas sedang kurang baik. Dalam dunia perbankan syariah likuiditas diukur dengan Financing to Deposit Ratio (FDR).

Atiqoh (2015) dalam penelitiannya terhadap bank umum konvensional yang terdaftar di Bursa Efek Indonesia menemukan bahwa LDR tidak berpengaruh terhadap NPL. Sedangkan penelitian Firmansyah (2014) justru membuktikan bahwa likuiditas yang diukur dengan FDR berpengaruh terhadap pembiayaan bermasalah BPRS di Indonesia. Dewi dan Ramantha (2015) dalam penelitiannya juga membuktikan bahwa likuiditas yang diukur dengan LDR berpengaruh terhadap NPL Bank BUMN di Indonesia.

Efisiensi bank syariah juga diprediksi dapat menjadi penyebab besarnya pembiayaan bermasalah. Efisiensi bank merupakan salah satu alat ukur kinerja yang mendasari seluruh kinerja sebuah bank. Dalam penelitian ini tingkat efisiensi bank di ukur dengan beban operasional pendapatan operasional (BOPO). BOPO atau Operating Expense to Operating Income dihitung dengan membandingkan antara Beban Operasi dengan Pendapatan Operasi atau yang biasa disingkat dengan BOPO. BOPO menunjukkan tingkat efisiensi suatu bank, sehingga semakin kecil rasio BOPO maka semakin efisien. Menurut Siamat (2005), biaya operasional terjadi karena adanya ketidakpastian mengenai usaha bank, antara lain kemungkinan kerugian dari kegiatan operasi jika terjadi penurunan keuntungan yang dipengaruhi oleh struktur biaya operasional bank dan kemungkinan terjadinya kegagalan atas jasa-jasa dan produk-produk baru yang ditawarkan. 
Menurut Dendawijaya (2003), rasio BOPO berpengaruh terhadap kredit bermasalah. Semakin kecil rasio BOPO berarti bank yang bersangkutan semakin efisien dalam mengelola biaya operasional. Dengan adanya efisiensi biaya maka bank akan memperoleh keuntungan yang optimal, bank mampu menambah jumlah pembiayaan yang disalurkan, biaya lebih kompetitif, pelayanan kepada nasabah menjadi lebih baik, bank menjadi lebih aman dan lebih sehat. Dengan efisiensi biaya yang baik, semakin kecil rasio BOPO maka kondisi bermasalah juga semakin kecil atau sebaliknya.

Firmansyah (2014) membuktikan bahwa BOPO yang menjadi ukuran efisiensi bank tidak berpengaruh terhadap pembiayaan bermasalah pada BPRS di Indonesia. Berbeda dengan Atiqoh (2015) yang membuktikan bahwa BOPO sebagai ukuran efisiensi berpengaruh terhadap NPL bank umum konvensional.

Permodalan yang diukur dengan Capital Adequacy Ratio (CAR) adalah rasio perbandingan jumlah modal baik modal inti maupun modal pelengkap terhadap Aktiva Tertimbang Menurut Risiko (ATMR). CAR merupakan ukuran yang digunakan Bank Indonesia dalam upaya menetapkan ketentuan penyediaan modal minimum bank. Semakin tinggi CAR maka semakin besar pula modal yang dimiliki. Dengan banyaknya modal, maka penyaluran kredit juga akan mengalami peningkatan, sehingga risiko terjadinya kredit bermasalah juga ikut meningkat. Menurut Jayanti (2013), semakin tinggi modal yang dimiliki bank maka akan semakin mudah bagi bank untuk membiayai aktiva yang mengandung risiko.

Hasil penelitian Atiqoh (2015) membuktikan bahwa permodalan berpengaruh terhadap NPL bank umum konvensional. Ramadhan (2017) dalam penelitiannya juga menemukan bahwa permodalan yang diukur dengan CAR berpengaruh terhadap pembiayaan bermasalah sektor pertambangan pada bank syariah. Sementara Barus dan Erick (2016) menemukan bahwa permodalan yang diukur dengan CAR tidak berpengaruh terhadap NPL pada bank umum di Indonesia.

Inflasi yang tinggi akan menyebabkan menurunnya pendapatan riil masyarakat sehingga standar hidup masyarakat juga turun. Sebelum inflasi, seorang debitur masih sanggup membagi pendapatannya untuk konsumsi dan menabung di bank, namun setelah inflasi terjadi, harga-harga mengalami peningkatan yang cukup tinggi, sedangkan penghasilan debitur tidak mengalami peningkatan, maka keinginan debitur untuk tetap menginvestasikan dananya di bank akan menurun sebab sebagian atau seluruh pendapatannya sudah dipakai untuk memenuhi kebutuhan rumah tangga sebagai akibat dari naiknya harga-harga. Menurunnya keinginan debitur untuk menginvestasikan dananya di bank akan menyebabkan penurunan jumlah dana pihak ketiga yang dapat dihimpun di bank. Semakin sedikitnya DPK yang dapat dihimpun oleh bank, jumlah kredit yang disalurkan juga akan berkurang, maka risiko terjadinya kredit bermasalah (NPL) akan menurun dan sebaliknya.

Firmansyah (2014) dalam penelitiannya membuktikan bahwa inflasi berpengaruh terhadap pembiayaan bermasalah BPRS di Indonesia. Demikian pula temuan Barus dan Erick (2016) yang juga membuktikan bahwa inflasi berpengaruh terhadap NPL bank umum di Indonesia. Berbeda dengan penelitian Asnaini (2014) yang justru menemukan bahwa inflasi tidak berpengaruh terhadap NPF bank umum syariah di Indonesia.

Rumusan masalah penelitian ini adalah apakah likuiditas, efisiensi, permodalan dan inflasi berpengaruh terhadap pembiayaan bermasalah bank syariah di Indonesia.

\section{KERANGKA TEORITIS DAN HIPOTESIS PENELITIAN}

Likuiditas yang diukur dengan Financing to Deposit Ratio (FDR) merupakan rasio untuk mengukur komposisi 
jumlah pembiayaan yang diberikan dibandingkan dengan jumlah dana pihak ketiga. Rasio ini mengukur likuiditas suatu bank. Semakin tinggi rasio FDR, maka semakin tidak likuid bank tersebut dikarenakan hampir seluruh dana yang dimiliki digunakan untuk pembiayaan. Jadi semakin tinggi rasio FDR, maka kemungkinan terjadi kredit bermasalah juga akan semakin tinggi. Dewi dan Ramantha (2015) dalam penelitiannya membuktikan bahwa likuiditas yang diukur dengan LDR berpengaruh terhadap NPL Bank BUMN di Indonesia. Hasil penelitian Astrini dkk (2014) menunjukkan bahwa LDR berpengaruh terhadap NPL bank yang terdaftar di BEI. Firmansyah (2014) juga membuktikan bahwa likuiditas yang diukur dengan FDR mempengaruhi pembiayaan bermasalah BPRS di Indonesia.

Menurut ketentuan Bank Indonesia, efisiensi operasi diukur dengan mengunakan rasio biaya operasional dibandingkan dengan pendapatan operasional (BOPO). Biaya dan pendapatan operasional bank didominasi oleh biaya bunga dan hasil bunga. Dendawijaya (2003) menjelaskan bahwa rasio BOPO berpengaruh terhadap kredit bermasalah. Semakin kecil rasio BOPO berarti semakin efisien bank tersebut. Dengan efisiensi biaya yang baik, semakin kecil rasio BOPO maka kondisi bermasalah juga semakin kecil, demikian pula sebaliknya. Hasil penelitian Atiqoh (2015) membuktikan bahwa BOPO sebagai ukuran efisiensi berpengaruh terhadap NPL bank umum konvensional.

Permodalan yang diukur dengan Capital Adequacy Ratio (CAR) adalah rasio perbandingan jumlah modal baik modal inti maupun modal pelengkap terhadap Aktiva Tertimbang Menurut Risiko (ATMR). Semakin tinggi CAR maka semakin besar pula modal yang dimiliki. Dengan banyaknya modal, maka penyaluran kredit juga akan mengalami peningkatan, sehingga risiko terjadinya kredit bermasalah juga ikut meningkat. Menurut Jayanti (2013), semakin tinggi modal yang dimiliki bank maka akan semakin mudah bagi bank untuk membiayai aktiva yang mengandung risiko. Hasil penelitian Atiqoh (2015) membuktikan bahwa permodalan berpengaruh terhadap NPL bank umum konvensional. Ramadhan (2017) dalam penelitiannya juga menemukan bahwa permodalan yang diukur dengan CAR berpengaruh terhadap pembiayaan bermasalah sektor pertambangan pada bank syariah. Demikian pula dengan penelitian Astrini dkk (2014) yang menemukan bahwa permodalan yang diukur dengan CAR berpengaruh terhadap NPL bank yang terdaftar di BEI.

Inflasi yang tinggi akan menyebabkan menurunnya pendapatan masyarakat sehingga standar hidup masyarakat juga turun. Sebelum inflasi, seorang debitur masih mampu mengalokasikan pendapatannya untuk konsumsi dan menabung di bank. Setelah inflasi terjadi, harga-harga menjadi naik, sedangkan penghasilan debitur tidak naik, sehingga keinginan debitur untuk tetap menyimpan dananya di bank akan menurun sebab sebagian atau seluruh penghasilannya sudah digunakan untuk memenuhi kebutuhan rumah tangga. Menurunnya keinginan debitur untuk menyimpan dananya di bank akan berdampak pada berkurangnya jumlah DPK yang dapat dihimpun di bank. Semakin sedikitnya DPK yang dapat dihimpun oleh bank, jumlah pembiayaan yang disalurkan juga akan berkurang, maka risiko terjadinya pembiayaan bermasalah akan menurun dan sebaliknya. Firmansyah (2014) dalam penelitiannya membuktikan bahwa inflasi berpengaruh terhadap pembiayaan bermasalah BPRS di Indonesia. Demikian pula temuan Barus dan Erick (2016) yang juga membuktikan bahwa inflasi berpengaruh terhadap NPL bank umum di Indonesia.

Berdasarkan kajian teori dan hasil penelitian sebelumnya maka kerangka pemikiran penelitian digambarkan sebagai berikut: 


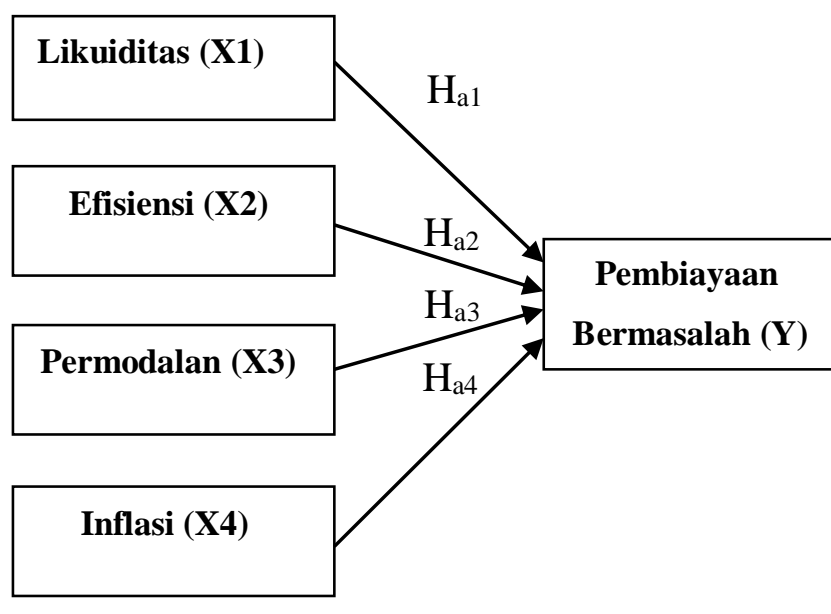

\section{Gambar 1. Kerangka Pemikiran}

Berdasarkan kerangka pemikiran yang bersumber dari kajian teori dan hasil penelitian sebelumnya, maka hipotesis yang diajukan dalam penelitian ini adalah sebagai berikut:

$\mathrm{H}_{\mathrm{a} 1}$ : Likuiditas berpengaruh terhadap pembiayaan bermasalah

$\mathrm{H}_{\mathrm{a} 2}$ : Efisiensi berpengaruh terhadap pembiayaan bermasalah

$\mathrm{H}_{\mathrm{a} 3}$ : Permodalan berpengaruh terhadap pembiayaan bermasalah

$\mathrm{H}_{\mathrm{a} 4}$ : Inflasi berpengaruh terhadap pembiayaan bermasalah

\section{METODE PENELITIAN}

Variabel dependen dalam penelitian ini adalah pembiayaan bermasalah. Variabel pembiayaan bermasalah diukur dengan rasio NPF bank syariah pada periode pengamatan. NPF menunjukkan perbandingan antara total pembiayaan bermasalah dengan total pembiayaan yang diberikan.

Variabel independen dalam penelitian ini adalah likuiditas, efisiensi, permodalan dan inflasi. Variabel likuiditas diukur dengan rasio FDR bank syariah pada periode pengamatan. FDR menunjukkan perbandingan antara total pembiayaan dengan total dana pihak ketiga. Variabel efisiensi diukur dengan rasio BOPO bank syariah pada periode pengamatan. BOPO menunjukkan perbandingan antara total biaya operasional dengan total pendapatan operasional. Variabel permodalan diukur dengan rasio CAR bank syariah pada periode pengamatan. CAR menunjukkan perbandingan antara modal bank dengan total ATMR (Aktiva Tertimbang Menurut Risiko). Variabel inflasi diukur dengan ndeks inflasi, yaitu tingkat inflasi yang erjadi pada periode pengamatan.

Populasi dalam penelitian ini adalah seluruh bank syariah yang secara statistik terdaftar di Otoritas Jasa Keuangan pada tahun 2015 sampai dengan tahun 2017. Adapun yang dijadikan sampel penelitian adalah data bulanan Bank Umum Syariah selama tiga tahun berturut-turut yaitu tahun 2015 sampai dengan tahun 2017. Akan tetapi karena data pada bulan Desember 2017 belum dipublikasikan maka data yang diamati adalah dari bulan Januari 2015 sampai dengan bulan November 2017 sehingga diperoleh 35 periode pengamatan.

Data penelitian berupa data sekunder yang berasal dari Otoritas Jasa Keuangan, yang bersumber dari Laporan Bulanan Bank Umum Syariah. Data sekunder ini diperoleh dari Statistik Perbankan Syariah. Data tersebut berupa data NPF, FDR, BOPO dan CAR Bank Umum Syariah selama periode pengamatan. Adapun data inflasi diperoleh dari situs resmi Bank Indonesia.

Data dikumpulkan melalui studi dokumentasi, yaitu dengan mengumpulkan data secara tidak langsung dalam rangka memperoleh informasi terkait objek penelitian. Data kemudian diolah dan dianalisis menggunakan analisis regresi berganda untuk menguji pengaruh variabel likuiditas, efisiensi, permodalan dan inflasi terhadap pembiayaan bermasalah pada Bank Umum Syariah di Indonesia selama periode pengamatan yaitu tahun 2015 sampai dengan tahun 2017. Data diolah menggunakan program IBM SPSS Statistics 21. Sebelum pengujian hipotesis dilakukan pengujian asumsi klasik terlebih dahulu. 


\section{HASIL DAN PEMBAHASAN}

\section{Hasil Uji Normalitas}

Berikut disajikan tabel hasil pengujian normalitas menggunakan uji KolmogorovSmirnov

Tabel 1. Hasil Uji Kolmogorov-Smirnov

\begin{tabular}{|ll|l|}
\hline & & \multicolumn{1}{|c|}{ Standardized Residual } \\
\hline N & & \multicolumn{2}{|c|}{35} \\
& Mean & Normal Parameters \\
& Std. Deviation & \\
Most Extreme Differences & Absolute & Most Extreme Differences \\
& Positive & \\
Kolmogorov-Smirnov Z & Negative &, 469 \\
Asymp. Sig. (2-tailed) & &, 980 \\
\hline
\end{tabular}

a. Test distribution is Normal.

b. Calculated from data.

Sumber: Data sekunder diolah (2018)

Berdasarkan tabel 1, disimpulkan bahwa data terdistribusi normal karena nilai Asymp. Sig. Standardized residualnya lebih besar dari 0,05 yaitu sebesar 0,980.

\section{Hasil Uji Multikolinearitas}

Berikut disajikan tabel hasil pengujian multikolinearitas dengan melihat nilai tolerance dan VIF.

Tabel 2. Hasil Uji Multikolinearitas

\begin{tabular}{|c|c|c|c|c|c|c|c|c|}
\hline \multirow{2}{*}{\multicolumn{2}{|c|}{ Model }} & \multicolumn{2}{|c|}{ Unstandardized Coefficients } & \multirow{2}{*}{$\begin{array}{c}\begin{array}{c}\text { Standardized } \\
\text { Coefficients }\end{array} \\
\text { Beta }\end{array}$} & \multirow[b]{2}{*}{$\mathrm{t}$} & \multirow[b]{2}{*}{ Sig. } & \multicolumn{2}{|c|}{$\begin{array}{c}\text { Collinearity } \\
\text { Statistics }\end{array}$} \\
\hline & & $\mathrm{B}$ & Std. Error & & & & Tolerance & VIF \\
\hline \multirow{5}{*}{1} & (Constant) & 8,159 & 5,617 & & 1,453 & 157 & & \\
\hline & FDR &, 024 & ,046 & , 197 &, 535 & ,597 & , 128 & 7,815 \\
\hline & BOPO &,- 006 &, 056 &,- 029 &,- 115 & ,910 & ,271 & 3,696 \\
\hline & CAR &,- 283 & , 128 &,- 607 & $-2,217$ & ,034 & ,231 & 4,328 \\
\hline & INFLASI &,- 038 & ,055 &,- 130 &,- 700 & -490 & 499 & 2,005 \\
\hline
\end{tabular}

a. Dependent Variable: NPF

Sumber: Data sekunder diolah (2018)

Berdasarkan tabel 2 dapat dilihat bahwa semua variabel independen memiliki nilai tolerance lebih dari 0,10 dan nilai VIF kurang dari 10 sehingga disimpulkan bahwa tidak terjadi gejala multikolinearitas.

\section{Hasil Uji Heteroskedastisitas}

Berikut disajikan tabel hasil pengujian heteroskedastisitas menggunakan uji glejser. 
Tabel 3. Hasil Uji Glejser

\begin{tabular}{|c|c|c|c|c|c|c|}
\hline & \multirow[t]{2}{*}{ Model } & \multicolumn{2}{|c|}{ Unstandardized Coefficients } & \multirow{2}{*}{$\begin{array}{r}\begin{array}{r}\text { Standardized } \\
\text { Coefficients }\end{array} \\
\text { Beta } \\
\end{array}$} & \multirow[b]{2}{*}{$\mathrm{t}$} & \multirow[b]{2}{*}{ Sig. } \\
\hline & & B & Std. Error & & & \\
\hline \multirow{5}{*}{1} & (Constant) & ,230 & 3,032 & & ,076 & ,940 \\
\hline & FDR &,- 030 & ,025 &,- 532 & $-1,202$ & 239 \\
\hline & BOPO & ,042 & ,030 & ,422 & 1,386 & , 176 \\
\hline & CAR &,- 075 & ,069 &,- 358 & $-1,086$ & ,286 \\
\hline & INFLASI &,- 049 & 030 &,- 369 & $-1,647$ &, 110 \\
\hline
\end{tabular}

a. Dependent Variable: ABRES

Sumber: Data sekunder diolah (2018)

Berdasarkan tabel 3 dapat dilihat bahwa nilai signifikansi masing-masing variabel independen lebih dari 0,05 sehingga dapat disimpulkan bahwa tidak terjadi gejala heteroskedastisitas pada data yang diuji.

\section{Hasil Uji Autokorelasi}

Berikut disajikan tabel hasil pengujian autokorelasi menggunakan uji Runs Test.

Tabel 4. Hasil Uji Runs Test

\begin{tabular}{|l|r|}
\hline & \multicolumn{1}{|c|}{ Unstandardized Residual } \\
\hline Test Value & \\
Cases $<$ Test Value &, 04727 \\
Cases >= Test Value & 17 \\
Total Cases & 18 \\
Number of Runs & 35 \\
$Z$ & \\
Asymp. Sig. (2-tailed) & 15 \\
\hline
\end{tabular}

a. Median

Sumber: Data sekunder diolah (2018)

Berdasarkan tabel 4 dapat dilihat bahwa nilai Asymp. Sig. (2-tailed) adalah 0,305 yang berarti bahwa data yang dipergunakan cukup random sehingga tidak terdapat masalah autokorelasi pada data yang diuji.

\section{Analisis Regresi Linear Berganda dan Hasil Uji Hipotesis}

Berikut disajikan tabel analisis regresi linear berganda dan hasil uji hipotesis menggunakan uji t yang dijadikan dasar dalam menyusun model regresi dan pengambilan keputusan diterima atau ditolaknya hipotesis penelitian.

Tabel 5. Analisis Regresi Linear Berganda dan Hasil Uji Hipotesis

\begin{tabular}{|rl|r|r|r|r|r|}
\hline \multirow{2}{*}{ Model } & \multicolumn{2}{|c|}{$\begin{array}{c}\text { Unstandardized } \\
\text { Coefficients }\end{array}$} & $\begin{array}{c}\text { Standardized } \\
\text { Coefficients }\end{array}$ & \multicolumn{1}{c|}{ Sig. } & \\
\cline { 3 - 5 } & \multicolumn{1}{|c|}{ B } & \multicolumn{1}{c|}{ Std. Error } & \multicolumn{1}{c|}{ Beta } & & \\
\hline \multirow{4}{*}{1} & (Constant) & 8,159 & 5,617 & & 1,453 &, 157 \\
& FDR &, 024 &, 046 &, 197 &, 535 &, 597 \\
& BOPO &,- 006 &, 056 &,- 029 &,- 115 &, 910 \\
& CAR &,- 283 &, 128 &,- 607 & $-2,217$ &, 034 \\
& INFLASI &,- 038 &, 055 &,- 130 &,- 700 &, 490 \\
\hline
\end{tabular}

a. Dependent Variable: NPF 
Sumber : Data sekunder diolah (2018)

Berdasarkan tabel 5, model regresi linear berganda dalam penelitian ini adalah:

\section{$\mathrm{NPF}=8,159+0,024$ FDR $-0,006$ BOPO - 0,283 CAR - 0,038 INFLASI + e}

Berdasarkan tabel 5 juga, hasil penelitian diuraikan sebaga berikut:

1. Nilai signifikansi variabel likuiditas yang diukur dengan FDR adalah sebesar 0,597. Karena nilai signifikansinya lebih besar dari 0,05 maka hipotesis bahwa likuiditas berpengaruh terhadap pembiayaan bermasalah tidak dapat diterima atau dengan kata lain ditolak.

2. Nilai signifikansi variabel efisiensi yang diukur dengan BOPO adalah sebesar 0,91. Karena nilai signifikansinya lebih besar dari 0,05 maka hipotesis bahwa efisiensi berpengaruh terhadap pembiayaan bermasalah tidak dapat diterima atau dengan kata lain ditolak.

3. Nilai signifikansi variabel permodalan yang diukur dengan CAR adalah sebesar 0,034. Karena nilai signifikansinya lebih kecil dari 0,05 maka hipotesis bahwa permodalan berpengaruh terhadap pembiayaan bermasalah diterima.

4. Nilai signifikansi variabel inflasi adalah sebesar 0,49 . Karena nilai signifikansinya lebih besar dari 0,05 maka hipotesis bahwa inflasi berpengaruh terhadap pembiayaan bermasalah tidak dapat diterima atau dengan kata lain ditolak.

Berdasarkan hasil pengujian hipotesis, penelitian ini menolak hipotesis pertama bahwa likuiditas berpengaruh terhadap pembiayaan bermasalah. Hasil penelitian menunjukkan bahwa likuiditas tidak berpengaruh terhadap pembiayaan bermasalah pada bank syariah di Indonesia. Hal ini mengindikasikan bahwa faktor likuiditas bukanlah menjadi penentu penyebab terjadinya pembiayaan bermasalah pada bank syariah.
Hasil penelitian ini sejalan dengan penelitian Atiqoh (2015) terhadap bank umum konvensional yang terdaftar di BEI bahwa LDR tidak berpengaruh terhadap NPL. Temuan penelitian ini berbeda dengan Firmansyah (2014) yang justru membuktikan bahwa likuiditas yang diukur dengan FDR berpengaruh terhadap pembiayaan bermasalah BPRS di Indonesia. Hasil penelitian ini juga tidak sejalan dengan penelitian Astrini dkk (2014) yang menunjukkan bahwa LDR berpengaruh terhadap NPL bank yang terdaftar di BEI, dan Dewi dan Ramantha (2015) yang membuktikan bahwa likuiditas yang diukur dengan LDR berpengaruh terhadap NPL Bank BUMN di Indonesia.

Penelitian ini menolak hipotesis ke dua bahwa efisiensi berpengaruh terhadap pembiayaan bermasalah. Hasil penelitian menunjukkan bahwa efisiensi tidak berpengaruh terhadap pembiayaan bermasalah pada bank syariah di Indonesia. Hal ini mengindikasikan bahwa faktor efisiensi bank tidak serta merta dapat mengurangi rasio pembayaran bermasalah. Hal ini disebabkan pembiayaan bermasalah adalah masalah eksternal bank syariah yang berkaitan dengan kewajiban debitur membayar utangnya dan bukan tergantung dari efisiensi operasional bank syariah. Dengan begitu efisiensi bukanlah faktor penentu bagi bank syariah dalam mengambil kebijakan mengenai pengelolaan pembiayaan bermasalah.

Temuan penelitian ini sejalan dengan penelitian Firmansyah (2014) yang membuktikan bahwa BOPO yang menjadi ukuran efisiensi tidak berpengaruh terhadap pembiayaan macet BPRS di Indonesia. Berbeda dengan Atiqoh (2015) yang membuktikan bahwa BOPO sebagai ukuran efisiensi berpengaruh terhadap NPL bank umum konvensional.

Hipotesis ke tiga yang diajukan dalam penelitian ini adalah permodalan berpengaruh terhadap pembiayaan 
bermasalah. Berdasarkan hasil pengujian hipotesis diperoleh temuan bahwa CAR sebagai ukuran permodalan berpengaruh terhadap pembiayaan bermasalah bank syariah. Dengan demikian hipotesis bahwa permodalan berpengaruh terhadap pembiayaan bermasalah diterima. Hal ini mengindikasikan bahwa semakin tinggi CAR maka semakin besar pula modal yang dimiliki. Dengan banyaknya modal, maka penyaluran kredit juga akan mengalami peningkatan, sehingga risiko terjadinya kredit bermasalah juga ikut meningkat.

Hasil penelitian ini sejalan dengan temuan Atiqoh (2015) bahwa CAR sebagai proksi permodalan berpengaruh terhadap NPL bank umum konvensional. Temuan ini sejalan juga dengan Ramadhan (2017) yang dalam penelitiannya juga menemukan bahwa permodalan yang diukur dengan CAR berpengaruh terhadap pembiayaan bermasalah sektor pertambangan pada bank syariah. Hasil penelitian ini sejalan juga dengan penelitian Astrini dkk (2014) yang menemukan bahwa permodalan yang diukur dengan CAR berpengaruh terhadap NPL bank yang terdaftar di BEI. Akan tetapi temuan penelitian ini bertentangan dengan temuan Barus dan Erick (2016) yang membuktikan bahwa permodalan yang diukur dengan CAR tidak berpengaruh terhadap NPL pada bank umum di Indonesia.

Hipotesis ke empat yang diajukan dalam penelitian ini adalah inflasi berpengaruh terhadap pembiayaan bermasalah. Berdasarkan hasil pengujian diperoleh temuan bahwa inflasi tidak berpengaruh terhadap pembiayaan bermasalah bank syariah. Dengan demikian disimpulkan bahwa hipotesis yang diajukan ditolak. Inflasi sebagai faktor eksternal ternyata tidak menjadi faktor penyebab terjadinya pembiayaan bermasalah.

Hasil penelitian ini sejalan dengan penelitian Asnaini (2014) yang menemukan bahwa inflasi tidak berpengaruh terhadap NPF bank umum syariah di Indonesia. Hasil penelitian ini tidak sejalan dengan
Firmansyah (2014) yang dalam penelitiannya membuktikan bahwa inflasi berpengaruh terhadap pembiayaan bermasalah BPRS di Indonesia, dan Barus dan Erick (2016) yang juga membuktikan bahwa inflasi berpengaruh terhadap NPL bank umum di Indonesia.

\section{SIMPULAN DAN SARAN \\ Simpulan}

1. Likuiditas tidak berpengaruh terhadap pembiayaan bermasalah bank syariah di Indonesia.

2. Efisiensi tidak berpengaruh terhadap pembiayaan bermasalah bank syariah di Indonesia.

3. Permodalan berpengaruh terhadap pembiayaan bermasalah bank syariah di Indonesia.

4. Inflasi tidak berpengaruh terhadap pembiayaan bermasalah bank syariah di Indonesia.

\section{Saran}

1. Penelitian ini hanya menggunakan empat variabel independen sehingga untuk penelitian yang akan datang diperlukan variabel lain supaya dapat diketahui penyebab lain terjadinya pembiayaan bermasalah pada bank syariah di Indonesia.

2. Periode penelitian hanya tiga tahun sehingga untuk menambah keyakinan hasil penelitian maka periode penelitian dapat diperpanjang.

3. Bank syariah hendaknya fokus terhadap permodalan mengingat bahwa permodalan berpengaruh terhadap pembiayaan bermasalah bank.

\section{DAFTAR PUSTAKA}

Asnaini, S.W. 2014. Faktor-Faktor Yang Mempengaruhi Non Performing Financing Pada Bank Umum Syariah di Indonesia. Jurnal TEKUN Vol.V(2), 264-280. 
Astrini, S., Suwendra, I.W., dan Suwarna, I.K. 2014. Pengaruh CAR, LDR dan Bank Size terhadap NPL Pada Lembaga Perbankan Yang Terdaftar di Bursa Efek Indonesia. e-Journal Bisma Universitas Pendidikan Ganesha Vol. 2

Atiqoh, N. 2015. Pengaruh CAR, LDR, BOPO, Inflasi dan GDP terhadap NPL (Studi Empiris Pada Bank Umum Konvensional Yang Terdaftar di BEI periode 2009-2013). Jurnal Ilmiah Universitas Bakrie Vol. 3(2).

Barus, A.C. dan Erick. 2016. Analisis FaktorFaktor Yang Mempengaruhi Non Performing Loan Pada Bank Umum di Indonesia. Jurnal Wira Ekonomi Mikroskill, Vol. 6(2), 113-122.

Dendawijaya, L. 2003. Manajemen Perbankan, Edisi Kedua. Ghalia Indonesia, Jakarta.

Dewi, K.P. dan Ramantha, I.W. 2015. Pengaruh Loan Deposit Ratio, Suku Bunga Sbi, Dan Bank Size Terhadap Nonperforming Loan. E-Jurnal Akuntansi Universitas Udayana, Vol. 11 (3), 909-920

Firmansyah, I. 2014. Determinant of Non Performing Loan: The Case of Islamic Bank in Indonesia. Buletin Ekonomi Moneter dan Perbankan 17(2), 241-258.

Ghozali, I. 2016. Aplikasi Analisis Multivariate Dengan Program SPSS 23, Edisi 8. BP Undip, Semarang.

Jayanti, K.D. dan Haryanto, A.M. 2013. Analisis Faktor-Faktor Yang Mempengaruhi Non Performing Loan (Studi Pada Bank Umum Konvensional yang Go Public di Indonesia Periode 2008-2012).
Disertasi, Fakultas Ekonomika dan Bisnis.

Mishkin, F.S. 2010. Ekonomi Uang, Perbankan dan Pasar Keuangan. Terjemahan Soelistianingsih, edisi 8. Salemba Empat, Jakarta.

Muhammad. 2005. Manajemen Bank Syariah. UPPAMP YKPN, Yogyakarta.

Peraturan BI No. 6/9/PBI/2004

Ramadhan, P. 2017. Determinan Pembiayaan Bermasalah Sektor Pertambangan Pada Perbankan Syariah. Akuntabilitas, Vol. 10(2), 369-390.

Riyadi, S. 2006. Banking Assets and Liability Management (Edisi Ketiga). Penerbit FEUI, Jakarta.

Siamat, D. 2005. Manajemen Lembaga Keuangan. Lembaga Penerbit Fakultas Ekonomi Universitas Indonesia, Jakarta.

http://www.republika.co.id/berita/ekonom i/syariah-

ekonomi/16/01/01/ekonomi/syariahekonomi/16/01/01/ekonomi/syariahekonomi/16/01/01/ekonomi/syariahekonomi/16/01/01/ekonomi/syariahekonomi/16/01/01/ekonomi/syariahekonomi/16/01/01/ekonomi/syariahekonomi/16/01/01/ekonomi/syariahekonomi/16/01/01/ekonomi/syariahekonomi/16/01/01/o091ib280-initantangan-perbankan-syariah-di-2016 diakses pada tanggal 26 September 2017

http://www.republika.co.id/berita/ekonom i/syariah-ekonomi/17/05/02/opb19v408pembiayaan-bermasalah-perbankansyariah-masih-tinggi diakses pada tanggal 29 September 2017 